Counsellia: Jurnal Bimbingan dan Konseling, 10 (1), $2020 \mid 1-13$.

Copyright @2020 Universitas PGRI Madiun

ISSN: 2088-3072 (Print) / 2477-5886 (Online)

Available online at: http://e-journal.unipma.ac.id/index.php/JBK

DOI: 10.25273/counsellia.v10i1.4730

\title{
Peningkatan Self-Regulated Learning Siswa melalui Konseling Ringkas Berfokus Solusi
}

\author{
Sri Rahayu Utami ${ }^{1}$, Wahyu Nanda Eka Saputra ${ }^{2}$, Siti Partini Suardiman ${ }^{3}$, Agus Ria \\ Kumara $^{4}$ \\ ${ }^{1}$ Fakultas Keguruan dan Ilmu Pendidikan, Universitas Ahmad Dahlan, Yogyakarta \\ sri1500001125@webmail.uad.ac.id \\ ${ }^{2}$ Fakultas Keguruan dan Ilmu Pendidikan, Universitas Ahmad Dahlan, Yogyakarta \\ wahyu.saputra@bk.uad.ac.id \\ ${ }^{3}$ Fakultas Keguruan dan Ilmu Pendidikan, Universitas Ahmad Dahlan, Yogyakarta \\ siti.partini@bk.uad.ac.id \\ ${ }^{4}$ Fakultas Keguruan dan Ilmu Pendidikan, Universitas Ahmad Dahlan, Yogyakarta \\ agus.kumara@bk.uad.ac.id
}

\begin{abstract}
Abstrak
Penelitian ini bertujuan mengetahui peningkatan self-regulated learning melalui konseling ringkas berfokus solusi di SMP Muhammadiyah Turi Sleman. Jenis pada penelitian ini adalah eksperimen dengan type one group pretest posttest design. Subjek penelitian ditentukan dengan teknik non probability sampling design menggunakan purposive sampling. Siswa kelas VIII SMP Muhammadiyah Turi Sleman merupakan subjek yang terlibat pada penelitian ini. Hasil penelitian dapat disimpulkan bahwa peningkatan self-regulated learning mengalami perbedaan yang signifikan sebelum dan sesudah diberikan layanan konseling ringkas berfokus solusi.
\end{abstract}

Kata kunci: Self-regulated learning, Konseling ringkas berfokus solusi

\begin{abstract}
This study aims to find out the improvement of self-regulated learning through concise counseling focusing solutions in SMP Muhammadiyah Turi Sleman. The type of this research is experiment with type one group pretest posttest design. The research subjects were determined by using a non-probability sampling design using purposive sampling. Class VIII students of SMP Muhammadiyah Turi Sleman were the subjects involved in this study. The results of the study concluded that the increase in self-regulated learning experienced significant differences before and after being given a concise solutionfocused counseling service.
\end{abstract}

Keywords: Self-regulated learning, Solutions Focused Group Brief Counseling.

\section{PENDAHULUAN}

Proses pembelajaran tidak hanya ditujukkan untuk mengembangkan self-regulated learning seperti aspek kognitif juga aspek afektif. Seseorang yang me miliki tujuan belajar mengenai strategi belajar efektif dengan cara dan waktu yang tepat merupakan pengertian dari self-regulated learning (Sumarmo, 2004). Pengertian lain self-regulated learning ialah peran aktif siswa merupakan proses dalam menyusun dan mengontrol 
kognisi yang meliputi motivasi serta perilaku berdasarkan tujuan belajar yang telah ditetapkan.

Self-Regulated Learning adalah suatu upaya untuk mengendalikan pikiran, perasaan dan perilaku dalam rangka mencapai suatu tujuan. Setiap manusia pasti memiliki tujuan, dan untuk mencapai tujuan tersebut semestinya harus fokus agar tujuan tersebut dapat tercapai. SRL pada siswa adalah kemampuan untuk mengembangkan srtrategi belajar mandiri pada diri siswa (Alhadi \& Supriyanto, 2017). Selaras dengan pendapat lain yang menjelaskan bahwa adanya perpaduan antara keterampilan dan keinginan atau yang disebut (skill) dan (will) merupakan pengertian dari self-regulated learning (Mukhid, 2008). Dipertegas dengan pendapat lain yang mengungkapkan bahwa self-regulated learning merupakan kemampuan yang diterapkan untuk menganalisis, menetapkan tujuan, merencanakan tugas belajar dan cara mengambil keputusan tentang penerapan gaya belajar (Woolfolk, 2010). Self-regulated learning ialah kegiatan seseorang belajar secara aktif mampu mengevaluasi secara sistematis dengan menggunakan berbagai strategi seperti kognitif, motivasional maupun behavioral sehingga mampu merencanakan tujuan belajar dan selanjutnya memantau tujuan belajar. (Suminarti, 2013).

Pembangkitan diri baik pikiran, perasaan serta tindakan yang direncakan yang berkaitan dengan pengelolaan diri dengan timbale balik disesuaikan dengan capaian tujuan personal. (Zimmerman, 1990). Atau bisa katakan metakognitif, motivasi dan prilaku saling berhubungan untuk mencapai tujuan. Pengaturan diri dan orientasi tujuan dalam belajar menunjukkan bahwa pembelajaran mandiri adalah fenomena yang kompleks dan beragam yang dapat menghasilkan orientasi tujuan yang tidak sederhana (Pintrich, 2000). Penilaian dan motivasi siswa untuk belajar di ibaratkan dengan hubungan ayam dan telur dimana setiap proses pembelajaran, penilaian dapat berfungsi sebagai tujuan; atau penilaian dapat berfungsi sebagai bantuan untuk penetapan tujuan, pemantauan, dan pembelajaran siswa (Panadero et al., 2018).

Untuk mencapai keberhasilan tujuan belajar tentu saja berhubungan dengan proses pembelajaran disekolah. Di mana sekolah merupakan unsur pendidikan pertama di samping keluarga dan masyarakat. Kegiatan pembelajaran diadakan untuk dapat merubah ilmu pengetahuan, tingkah laku, sikap, keterampilan, kebiasaan dan lainnya dengan harapan perubahan proses pembelajaran dapat terjadi sesuai tujuan yang diinginkan. Keberhasilan siswa dalam belajar dipengaruhi oleh berbagai faktor, diantaranya faktor eksternal internal, melalui tiga tahapan yaitu faktor jasmani, rohani dan faktor psikologis (Mulyani, 2013). Kegiatan untuk melakukan perubahan pada siri seseorang baik berupa perubahan sikap, kebiasaan dan tingkah laku. Perubahan tersebut dapat dikatakan tujuan dari proses pembelajaran.

Peserta didik dapat mencapai tujuan belajar dengan baik apabila mengikuti proses pembelajaran dengan baik (Yulianti et al., 2016). Peserta didik berperan aktif pada proses pembelajaran sehingga proses pembelajaran dapat terlaksana dengan baik. Namun, dalam proses belajar, tentunya berkaitan dengan macam-macam kesulitan belajar. Strategi dalam menentukkan tujuan belajar lebih efektif merupakan suatu hal yang dapat mempengaruhi proses pembelajaran. Karena nantinya berhubungan dengan self-regulated learning serta keefektifan strategi belajar. Pada proses pembelajaran self-regulated learning sangat diperlukan oleh peserta didik dalam berbagai aktivitas yang dilakukan khususnya dalam aktivitas pembelajaran (Andrew \& Vialle, 1998; Khafidhoh \& Purwanto, 2015; Latipah, 2010; Pintrich \& De Groot, 1990; Yulianti et al., 2016; Zimmerman, 1990). Dengan adanya self-regulated learning, keberhasilan seseorang tidak hanya ditinjau dari faktor 
lingkungan, melainkan ditinjau dari kesanggupan individu merancang strategi untuk meningkatkan potensi belajarnya. Kemampuan memantau pikiran, perasaan, dan perilaku dalam mencapai tujuan akademik maupun tujuan sosio-emosional merupakan arti selfregulated learning.

Self-regulated learning biasa juga diartikan dengan gabungan antara pengendalian dan keterampilan diri dalam belajar menjadikan siswa lebih temotivasi dan memudahkan proses pembelajaran. Siswa dengan self-regulated learning tinggi memungkinan siswa tersebut berprestasi dalam belajarnya juga tinggi (Latipah, 2010). Sama halnya dengan pendapat Bembenutty yang menyebutkan self-regulated learning ialah proses adanya keterlibatan pikiran, tindakan dan perasaan saat mengejar tujuan akademik. Seseorang yang paling sukses ialah orang yang menggunakan strategi belajar yang tepat dan pertahankan tingkat motivasi yang tinggi (Bembenutty, 2007).

Strategi yang mendukung untuk proses belajar ialah dengan keterampilan mengatur kegiatan belajar menggunakan strategi belajar efktif sehingga mengetahui tujuan strategi lain yang mendukung proses pembelajaran. Karakteristik self-regulated learning bertujuan memperluas pengetahuan sehingga individu memiliki strategi untuk mengelola emosinya dalam memonitor tujuan belajarnya, menyesuaikan dan mampu mengevaluasi hambatan yang mungkin timbul dan diperlukan adaptasi. Self-regulated learning di klasifikasikan menjadi dua faktor, yaitu faktor kognitif berhubungan dengan informasi dan faktor metakognitif berhubungan dengan kondisi pembelajaran yang diperlihatkan selama situasi belajar (Mukhid, 2008).

Seseorang yang paling sukses ialah orang yang menggunakan strategi belajar yang tepat dan mampu mempertahankan tingkat motivasi yang tinggi. Siswa membutuhkan self-regulated learning agar individu mampu menyesuaikan, mengarahkan, dan mengatur diri. Peserta didik mampu mengetahui mencapai suatu tujuan belajar, mampu mengontrol, merencanakan dan mampu mengatur proses mental merupakan ciri siswa dengan selfregulated learning tinggi. Proses pendidikan dengan penggunaan bahan ajar pembelajaran maupun pelayanan bimbingan dan konseling di anggap mampu untuk proses pengembangan self-regulated learning pada diri siswa (Alhadi \& Supriyanto, 2017). Self-regulated learning melibatkan kemampuan motivasi, metakognitif dan perilaku yang diyakini sebagai tingkatan dimana dalam proses belajar individu. Sedangkan menurut pendapat lain dijabarkan bahwa kegiatan pembelajaran yang secara otonomi berkaitan dengan motivasi belajar disebut dengan self-regulated learning (Zimmerman, 1990).

Pada kenyataannya dalam proses pembelajaran siswa masih tidak membuat perencanaan belajar dan melakuakan evaluasi. Siswa yang tidak disiplin dalam mengerjakan tugas yang tidak sesuai dengan petunjuk pengerjaan, dan tidak mengumpulkan tugas rumah, dan terlambat datang sekolah, masih sibuk sendiri ketika guru menerangkan, nongkrong di kantin ketika jam pelajaran, menyontek, kemudian hasil PTS (Penilaian Tengah Semester) yang rendah sehingga harus mengikuti remidial di beberapa mata pelajaran. Fenomena ini mengindikasikan bahwa rendahnya regulasi diri dalam belajar sehingga mengakibatkan rendahnya kemampuan prestasi akademik siswa.

Hal berikut menunjukkan hasil belajar yang belum optimal, dimana siswa yang mempunyai kemampuan rendah dalam meregulasi dirinya. Hasil dari studi pendahuluan yang telah dilakukan kepada siswa kelas VIII SMP Muhammadiyah Turi Sleman, Dari hasil studi pendahuluan yang telah dilakukan di kelas VIII SMP Muhammadiyah Turi Sleman menunjukkan hasil bahwa 14,286\% memiliki tingkat self-regulated learning tinggi, 52,380\% memiliki tingkat self-regulated learning sedang dan 61,905\% memiliki tingkat self-regulated learning rendah. Wawancara yang dilakukan guru BK dapat memperkuat penjelasan perilaku siswa yang menunjukkan perilaku seperti dengan tidak 
membawa buku pelajaran, salah jadwal, tidak mengerjakan tugas, mengerjakan tugas di sekolah, siswa belum banyak membuat perencanaan belajar setiap harinya disebabkan berbagai faktor dari keluarga dan lingkungan. Upaya guru BK sudah diberikan layanan berupa layanan bimbingan dan konseling dengan teknik informasi namun dirasa belum efektif. Layanan bimbingan dan konseling dalam upaya meningkatkan self-regulated learning sudah pernah diberikan namun hasil yang di capai belum efektif. Maka dari itu, diperlukan bantuan dari guru BK untuk membantu siswa meningkatkan regulasi diri dalam belajar agar hasil belajar dapat tercapai dengan lebih efektif. Intervensi yang diberikan ialah pendekatan konseling ringkas berfokus solusi. Proses konseling model ini berupaya agar lebih memfokuskan pada solusi bukan hanya terfokus pada masalah. Dengan harapan mempercepat konseli untuk menemukan solusi lebih cepat pada saat proses konseling yang dilakukan.

Solution Focused Therapy, dan Solution Focused Brief Counseling Constructivist ini juga sering disebut sebagai Therapy atau konseling ringkas berfokus solusi (Sumarwiyah et al., 2015). Model Solution Focused Brief Counseling (SFBC) mendorong konseli menyadari keterampilannya untuk memunculkan cara yang paling tepat atau solusi untuk masalahnya sendiri (Nelson \& Thomas, 2012; Rusandi \& Rachman, 2014; Saputra, Da Costa, et al., 2018; Sumarwiyah et al., 2015; Wahyuni, 2015; Wiyono, 2015). Perubahan yang terjadi setelah penerapan konseling ialah perubahan teraupetik untuk meningkatkan harga diri individu. (Rusandi \& Rachman, 2014). Pandangan teori konseling ini menyebutkan bahwa setiap individu sehat dan kompeten dalam kemampuan membangun solusi yang optimal. Asumsi pokok konseling ringkas berfokus solusi ini ialah setiap manusia memiliki kemampuan mengatasi masalah, walaupun kadang individu tidak sadar akan kemampuan yang ia miliki (Corey, 2012).

Self-regulated learning adalah keadaan dimana proses pembelajaran memiliki kontrol pada pemahaman proses belajar, penerapan strategi belajar, dan pengambilan keputusan. Konseling ringkas berfokus solusi ialah konseling ringkas yang dibentuk berdasarkan power konseli membangun solusi terhadap masalah yang dihadapi. Latifah meneliti tentang strategi self regulated learning dan prestasi menyatakan bahwa siswa dengan regulasi diri tinggi tidak hanya paham dengan apa yang dibutuhkan, tetapi individu juga dapat menerapkan strategi yang diperlukan pada setiap pelajaran. Selain itu seorang self-regulated learner juga dapat bertanggung jawab terhadap kegiatan belajarnya (Latipah, 2010). Maka dari itu, peningkatan self-regulated learning berdampak pula pada peningkatan prestasi akademiknya. dengan berbantuan guru BK kepada siswa dengan menerapkan konseling Solution Focused Brief Counseling (SFBC). Pada konseling model ini memiliki upaya untuk lebih fokus pada solusi bukan terpaku pada masalah. Konseling ringkas berfokus solusi memiliki efikasi tinggi untuk menjadi langkah konselor membantu konseli keluar dari masalahnya. Pendekatan ini mempercayai bahwa dengan perubahan yang berkelanjutan sehingga sikap siswa dapat diubah menjadi lebih baik.

Menurut pandangan pendekatan konseling ringkas berfokus solusi individu memiliki kemampuan yang kompeten dalam membangun solusi sehingga tidak tefokus permasalahan. Para peneliti lain juga menujukkan jika konseling model ini berhasil digunakan untuk menyelesaikan permasalahan yang sejalan dengan self-regulated learning. Atas asumsi tersebut, terlebih sejauh ini belum banyak peneliti yang meneliti tentang peningkatan self-regulated learning melalui konseling ringkas berfokus solusi untuk, maka peneliti tertarik membuat penelitan dengan tema "Peningkatan SelfRegulated Learning siswa melalui konseling ringkas berfokus solusi”. 


\section{METODE PENELITIAN}

\section{Rancangan Penelitian}

Pada penelitian ini, pendekatan yang digunakan peneliti adalah pendekatan kuantitatif dengan desain penelitian eksperimen. Menurut Suharsimi, Penelitian yang dituntut menguatkan angka, serta pengumpulan data, penafsiran terhadap data tersebut, serta penampilan hasilnya merupakan pengertian dari penelitian kuantitatif (Suharsimi, 2002). Sedangkan penelitian yang dipakai untuk mencari pengaruh tertentu, perlakuan terhadap orang lain pada kondisi yang terkendali disebut penelitian eksperimen (Sugiyono, 2010).

Metode penelitian eksperimen adalah metode penelitian yang digunakan untuk mencari pengaruh pelakuan tertentu terhadap yang lain dalam kondisi yang terkendali. Peneliti dilakukan random individu ditugaskan ke kelompok, sedangkan kelompok satu menerima treatment dan kelompok dua tidak, kegiatan eksperimen tersebut dapat dikatakan treatment pengobatan sehingga hasilnya bukan dipengaruhi oleh factor lain (Creswell, 2009).

Bentuk design pre-eksperimental dengan model pada penelitian ini ialah model one group pretest-postttest design. Dalam penelitian ini terdiri hanya dari suatu kelompok saja dalam kelompok eksperimen yang mendapat perlakuan, sehingga hasil perlakuan dapat diketahui lebih akuran dengan membandingkan dengan keadaan sebelum di berikan perlakuan.

\section{Sumber Data}

Wilayah general terdiri atas subjek, objek dan karakteristik tertentu yang ditetapkan oleh peneliti yang kemudian disimpulkan disebut populasi (Sugiyono, 2010). Dalam penelitian ini yang menjadi subjek populasi adalah seluruh siswa kelas VIII sebanyak 3 kelas yang berjumlah 65 siswa. Adapun rincian siswa terlihat pada tabel berikut.

Tabel 1. Populasi penelitian

\begin{tabular}{ccc}
\hline No & Kelas & Jumlah Siswa \\
\hline 1. & Kelas VIII A & 21 Siswa \\
\hline 2. & Kelas VIII B & 22 Siswa \\
\hline 3. & Kelas VIII C & 22 Siswa \\
\hline & Jumlah & 65 Siswa \\
\hline
\end{tabular}

Sampel merupakan sebagian atau wakil populasi yang di teliti (Suharsimi, 2002). Disesuaikan dengan pendapat ahli, sampel ialah bagian populasi dan mewakili populasi dalam penelitian. Penentuan subjek penelitian ini menggunakan teknik Nonprobability Sampling Design yang digunakan ialah Purposive Sampling. Pengambilan sampel data pada sumber data dengan pertimbangan tertentu disebut dengan metode purposive sampling (Sugiyono, 2010). Subjek pada penelitian ini yaitu sebagian siswa kelas VIII SMP Muhammadiyah Turi yang dipilih dari hasil pre-test menggunakan skala selfregulated learning dengan hasil tingkat self-regulated learning rendah yang representatif. Subjek dari penelitian ini memiliki ciri-ciri sebagai berikut:

a. Siswa pada tingkat SMP dengan tingkat self-regulated learning yang rendah sesuai hasil pre-test.

b. Berjenis kelamin laki-laki atau perempuan.

c. Siswa kelas VIII SMP Muhammadiyah Turi.

d. Mendapat persetujuan dari orang tua dan guru BK

e. Bersifat kooperatif 


\section{Teknik Pengumpulan Data}

Instrumen pada penelitian ini menggunakan instrumen skala self-regulated learning dan pedoman observasi. Terdapat 22 pertanyaan skala self-regulated learning yang sudah tervalidasi. 0,924 merupakan nilai koefisien pada alpha cornbach penelitian ini. Sehingga dapat ditarik kesimpulan masuk dalam kategori reliabilitas yang tinggi. Berikut kisi-kisi instrument yang digunakan dalam penelitian ini:

Tabel 2. Kisi-kisi Instrumen Skala Self-rgulated learning setelah uji coba

\begin{tabular}{|c|c|c|}
\hline Variabel & Indikator & Deskriptor \\
\hline \multirow{9}{*}{$\begin{array}{l}\text { Self-Regulated } \\
\text { Learning }\end{array}$} & \multirow{4}{*}{ Metakognitif } & Merencanakan dan menetapkan tujuan belajar \\
\hline & & Siswa mampu memanajemen waktu belajar \\
\hline & & Mampu memonitor dan mengevaluasi kegiatan belajar \\
\hline & & Memahami pelajaran yang diberikan \\
\hline & \multirow{3}{*}{ Motivasi } & Mampu menyelesaikan tugas \\
\hline & & Membangun kepercayaan diri siswa terhadap kemampuannya \\
\hline & & Memiliki semangat yang tinggi \\
\hline & \multirow{2}{*}{ Perilaku } & Mengatur stratagei belajar \\
\hline & & Mampu memilih, menyusun dan menciptakan lingkungan belajar \\
\hline
\end{tabular}

\section{Teknik Analisis Data}

Langkah yang paling penting dalam suatu kegiatan penelitian disebut dengan analisisi data. Digunakan analisis data untuk mengukur keefektifan konseling pendekatan konseling ringkas berfokus solusi pada siswa kelas VIII SMP Muhammadiyah Turi. Analisis data dilakukan untuk mengetahui data kondisi setelah dilakukan treatment di tinjau dari kondisi sebelumnya untuk mengetahui peningkatan tingkat self-regulated learning. keseluruhan data dilakukan dengan cara menghitung secara manual untuk mencari tingkat self-regulated learning.

Metode analisis data adalah cara mengolah data yang diperlukan untuk penelitian. Sebelum ditarik kesimpulan, data haruslah diolah terlebih dahulu. Data penelitian terkumpul secara kuantitatif (angka) yang dapat diolah selanjutnya dianalisis dengan cara statistik dengan rumus t-test. Pengolahan data penelitian kuantitatif menggunakan alat yang disebut statistika. Pada statistika, data disingkat menjadi ukuran-ukuran statistik seperti rata-rata, $\mathrm{t}$ hitung, $\mathrm{r}$ hitung, $\mathrm{F}$ hitung, dan sebagainya tergantung masalah yang hendak dijawab. Untuk mencari kenaikan dari tingkat SRL siswa keseluruhan komputasi datadibantu dengan fasilitas perangkat lunak program (Statistical Package For Social Science).

\section{HASIL DAN PEMBAHASAN}

\section{Hasil Penelitian}

Data yang telah didapatkan selanjutnya diolah dengan bantuan program microsoft excel (data pretest dan posttest self-regulated learning). Deskripsi hasil pretest dan posttest skala self-regulated learning siswa kelas VIII SMP Muhammadiyah Turi ditampilkan pada tabel 3 . 
Tabel 3. Deskripsi Skor self-regulated learning siswa kelas VIII SMP Muhammadiyah Turi Sleman

\begin{tabular}{|c|c|c|c|c|c|c|}
\hline \multirow{2}{*}{ No } & \multirow{2}{*}{ Subjek } & \multicolumn{4}{|c|}{ Skor dan Kategori } & \multirow{2}{*}{ Gain (d) } \\
\hline & & \multicolumn{2}{|c|}{ Pretest } & \multicolumn{2}{|c|}{ Posttest } & \\
\hline 1 & AP & 43 & Rendah & 75 & Tinggi & 32 \\
\hline 2 & SH & 43 & Rendah & 74 & Tinggi & 31 \\
\hline 3 & MK & 40 & Rendah & 66 & Sedang & 26 \\
\hline 4 & MM & 42 & Rendah & 68 & Tinggi & 26 \\
\hline Total & $\mathbf{N}=4$ & 168 & & 283 & & $\sum d=115$ \\
\hline & ean & 42 & & $\mathbf{7 0 , 7 5}$ & & 28,75 \\
\hline
\end{tabular}

Penjabaran tabel 1 dapat dijelaskan bahwa terjadi kenaikan pada tingkat selfregulated learning dari yang awalnya berkategori rendah menjadi naik menjadi kategori sedang maupun tinggi. Hasil self-regulated learning dengan mendapatkan skor rata-rata sebesar 28,75 poin. Sebelum diberikan treatment memperoleh skor 42 sedangkan setelah dilakukan treatmen menunjukkan adanya kenaikan menjadi 70,75. Penelitian ini menunjukan hasil penelitian self-regulated learning meningkat yang signifikan adalah pada subjek AP dengan 32 skor. Sedangkan kenaikan self-regulated learning paling kecil yaitu pada subjek MK yaitu dengan besar skor 26.

Gambar grafik secara visual peningkatan self-regulated learning siswa SMP Muhammadiyah Turi Sleman :

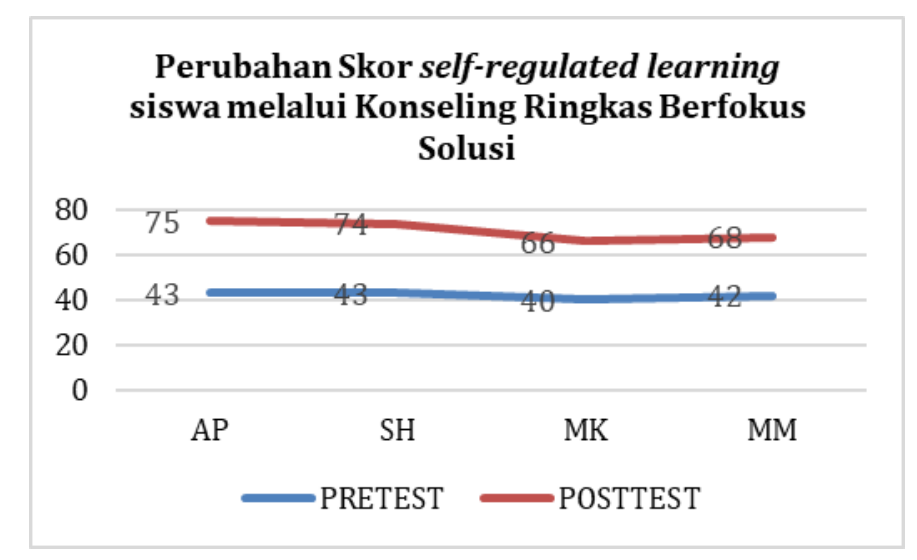

Gambar 1 Perbedaan skor Perilaku self-regulated learning berubah setelah proses konseling ringkas berfokus solusi

Dapat terlihat dari gambar grafik diatas, bahwa terjadi adanya kenaikan tingkat self-regulated learning pada siswa setelah mengikuti layanan konseling ringkas berfokus solusi. Hal ini di tunjukan dengan posttest grafik berwarna merah yang lebih tinggi dari pada garis berwarna biru yang merupakan grafik pretest. Dari grafik tersebut dapat di simpulkan setelah proses layanan kosenling ringkas berfokus solusi terlaksana terdapat peningkatan skor self-regulated learning. Pada derajat bebas $(\mathrm{db})=\mathrm{n}-1=4-1=3$ dengan taraf signifikan $(\alpha)=5 \%$ nilai $\mathrm{t}$ tabel $=2,353$ sehingga Ho ditolak jika nilai $\mathrm{t}$ hitung $>\mathrm{t}$ tabel $(2,353)$ dan Ho diterima jika nilai $t$ hitung $\leq 2,353$. Tabel hasil perhitungan nilai $t$ hitung dengan menggunakan bantuan SPSS, disajikan pada table 4. 
Tabel 4. Paired Sample Test Hasil Penilaian t-hitung

\begin{tabular}{|c|c|c|c|c|c|c|c|c|c|}
\hline & & \multicolumn{5}{|c|}{ Paired Differences } & \multirow[b]{3}{*}{$\mathrm{t}$} & \multirow[b]{3}{*}{ Df } & \multirow[b]{3}{*}{ Sig. (2-tailed) } \\
\hline & & \multirow[b]{2}{*}{ Mean } & \multirow{2}{*}{$\begin{array}{c}\text { Std. } \\
\text { Deviation }\end{array}$} & \multirow{2}{*}{$\begin{array}{l}\text { Std. Error } \\
\text { Mean }\end{array}$} & \multicolumn{2}{|c|}{$\begin{array}{l}\text { 95\% Confidence Interval of } \\
\text { the Difference }\end{array}$} & & & \\
\hline & & & & & Lower & Upper & & & \\
\hline Pair 1 & $\begin{array}{l}\text { PRETEST - } \\
\text { POSTTEST }\end{array}$ & $-28,75000$ & 3,20156 & 1,60078 & $-33,84440$ & $-23,65560$ & $-17,960$ & 3 & ,000 \\
\hline
\end{tabular}

Berdasarkan tabel tersebut maka dapat diketahui bahwa nilai t-hitung sebesar 17,960. Perhitungan pada table diperoleh nilai berdasarkan $\mathrm{t}_{\text {hitung }}=-17,960>2,353\left(\mathrm{t}_{\text {tabel }}\right)$ pada taraf signifikan $(\alpha)=5 \%$ sehingga Ho ditolak yang menunjukkan bahwa ada peningkatan self-regulated learning yang signifikan setelah diberikan layanan konseling ringkas berfokus solusi pada siswa kelas VIII SMP Muhammadiyah Turi Sleman. Sehingga hipotesis penelitian ini adalah: "self-regulated learning siswa kelas VIII SMP Muhammadiyah Turi Sleman efektif dapat ditingkatkan melalui proses konseling ringkas berfokus solusi" teruji kebenarannya.

Hasil proses layanan konseling ringkas berfokus solusi menunjukkan hasil yang berbeda-beda pada masing-masing konseli, yaitu Subjek AP, SH, MK, dan MM. Selain berdampak menurunkan perilaku prokrastinasi akademik yang dapat terlihat pada hasil pretest dan posttest, didukung juga dari hasil observasi yang dilakukan peneliti kepada konseli setelah dilaksanakannya treatment.

\section{Profil AP}

Berdasarkan perbandingan hasil pretest dan posttest menunjukkan bahwa AP mengalami kenaikan sebanyak 32 poin dari yang semula berkategori rendah menjadi kategori tinggi. AP mendapat selisih kenaikan pretest dan posttest paling tinggi diantara teman-teman yang lainnya. Pada saat treatment dilaksanakan AP masih belum mampu mengatur strategi belajarnya sehingga peringkat kelas AP menurun dari semester sebelumnya AP belum mampu mengevaluasi apa yang menjadi kekurangan dalam belajarnya, namun setelah diberikan layanan dari hasil observasi menunjukkan bahwa AP sudah mulai memahami strategi belajar dengan cara mengetahui gaya belajar yang tepat sehingga AP mempunyai motivasi kembali untuk bisa memperbaiki peringkatnya.

Profil SH

SH mendapatkan kenaikan poin 31 poin dari perbandingan nilai pretest dan posttest menjadikan SH dari yang awalnya berkategori rendah menjadi kategori tinggi. Pada saat proses treatment SH merupakan siswa yang paling aktif diantara siswa lainnya. Hasil dari observasi menunjukkan bahwa ketika jam istirahat SH lebih memilih belajar dari pada bermain HP dengan temannya.

Profil MK

MK merupakan subjek yang mendapat kenaikan hasil nilai yang rendah. Perbandingan nilai pretest dan posttest menunjukan hasil dari yang tadinya Mk berkategori rendah naik menjadi kategori sedang. Hasil observasi menunjukkan bahwa MK langsung mencatat materi yang di sampaikan guru tanpa di suruh dan mengikuti pelajaran di kelas hingga pelajaran selesai.

Profil MM

Pada saat proses pemberian treatment layanan konseling MM merupakan anak yang pendiam. MM mendapat selisih kenaikan pretest posttest yaitu 26 point yang membawanya dari kategori rendah menjadi kategori tinggi. Salah satu dampak dari proses konseling ini dan di dukung dengan hasil observasi yaitu MM sudah mulai menunjukkan kemampuannya untuk mengemukaan pendapat maupun berbicara di depan kelas serta aktif ketika proses belajar berlangsung. 


\section{Pembahasan}

Hasil penelitian ini menunjukkan bahwa layanan konseling ringkas berfokus solusi mampu efektif dan dapat menjadi intervensi sebagai alternatif bantuan untuk meningkatkan self-regulated learning. satu model konseling masa kini yang dikategorikan efektif untuk digunakan konselor dalam membantu konseli keluar dari permasalahan yang dialami merupakan pengertian dari konseling ringkas berfokus solusi atau dikenal dengan sebutan SFBC (Solution Focused Brief Counseling) (Saputra dkk., 2018). Dipertegas Corey yang menyebutkan proses konseling yang di dasari oleh suatu pandangan bahwa kebenaran dan realitas bukanlah suatu yang bersifat mutlak. Pada proses konseling dengan pendekatan ini memicu konseli dapat secara mandiri menyelesaikan, dan mencari solusi secara cepat dan tepat dalam menyelesaikan permsasalahan yang dialami (Corey, 2012).

Pendekatan teknik konseling ringkas berfokus solusi ini berpendapat bahwa setiap individu mempunyai solusi untuk pemecahan masalah tersebut, namun kadang individu terlalu terpaku pada permasalahan sehingga lupa dengan kelebihan yang ia miliki (Corey, 2015). Hal tersebut berkaitan dengan seseorang yang mempunyai self-regulated learning rendah, dimana seseorang yang memiliki self-regulated learning rendah cenderung kehilangan motivasi, tidak terbiasa menggunakan strategi belajar, dan tidak mampu menetapkan tujuan akademik untuk mengembangkan self-regulated learning. Peningkatan self-regulated learning melalui konseling ringkas berfokus solusi dipercaya bahwa siswa mampu melakukan perubahan yang berkelanjutan. sesuai dengan pendapat konseling ringkas berfokus solusi yang memandang setiap individu mampu dan mempunyai solusi sendiri untuk setiap masalah yang dihadapinya.

Konseling yang berfokus pada solusi didasarkan pada asumsi bahwa solusi harus ditemukan melalui proses perubahan interaksi dan penciptaan makna baru bagi masalah klien serta klien dapat memecahkan masalah dan mengatasi pola kebiasaan. Asumsi ini didukung oleh pendapat lain yang mendasari bahwa perubahan kecil menyebabkan perubahan dalam sistem secara keseluruhan, perubahan adalah konstan, masalah yang terjadi secara terus menerus dan bervariatif, optimisme konseli dengan menciptakan ekspektasi positif bahwa perubahan itu mungkin terjadi, berorientasi pada masa depan bukan masa lalu, dan berfokus pada solusi bukan masalah.

Pada penelitian ini tahapan yang diterapkan meliputi (1) membina hubungan; (2) identifikasi masalah yang dipecahkan; (3) penetapan tujuan; (4) perumusan dan implementasi solusi; dan (5) termination, evaluation dan tindak lanjut (Corey, 2015). Tahapan konseling ini yang memandu konselor dalam mengimplementasikan konseling ringkas berfokus solusi untuk meningkatkan self-regulated learning. Pada tahap membina hubungan agar mencapai perubahan yang diharapkan, konselor dengan konseli diperlukan jalinan komunaksi yang baik dan kolaboratif. Salah satu langkah yang dapat dilakukan agar segera berinteraksi dengan konseli dapat membangun kesadaran konseli pada awal proses konseling adalah dengan memulai percakapan topic netral sebagai pengembangan sosial dari permasalahan yang dihadapi.

Tahap yang kedua adalah identifikasi masalah yang dipecahkan. Tahap ini merupakan salah satu langkah dalam proses konseling yang dapat mengembangkan tujuan dan intervensi yang dapat meningkatkan perubahan. Pertanyaan yang digunakan konselor sehingga membangun komunikasi yang optimis dengan harapan berubah. Teknik yang digunakan konselor pada tahap ini ialah acceptance, summarizing, klarifikation, open question, dan teknik-teknik dasar komunikasi konseling yang lain. Kondisi konseli dapat dipahami secara terperinci dan jelas. Scaling question dapat digunakan untuk mengetahui dasar dari kondisi konseli dan mengidentifikasi kemungkinan-kemungkinan serta kemajuan konseli saat proses konseling. 
Tahap selanjutnya, tahap ketiga ialah penetapan tujuan. Tahapan ini konselor mendorong konseli untuk merancang tujuan yang ingin dicapai oleh konseli. Konselor menggunakan teknik miracle question untuk mempromosikan perumusan tujuan dari konseli. Beberapa hal spesifik yang dilakukan konselor antara lain merubah apa yang dilakukan pada saat berada dalam situasi masalah, merubah sudut pandang permasalahan yang dihadapi atau kerangka pikir tentang situasi yang sedang dihadapi, dan mencari kelebihan yang dimiliki oleh konseli untuk memunculkan sumber solusi.

Tahap yang keempat adalah merumuskan dan mengimplementasikan solusi. Pada tahap ini konselor merancang sebuah intervensi alternatif cara mereaksi masalah dari berbagai bentuk perilaku bermasalah. Startegi konseling digunakan konselor untuk memacu terjadinya perubahan sesuatu meskipun tidak begitu terlihat. Dalam tahap ini konseli diberi kesempatan untuk mengaplikasikan alternatif intervensi untuk menghadapi masalahnya sendiri antar sesi pertemuan dalam konseling.

Tahap yang kelima adalah evaluasi, terminasi, dan tindak lanjut. Teknik yang digunakan pada tahap ini ialah scaling question untuk melihat perubahan yang terjadi pada konseli berdasarkan dengan perbadingan yang terjadi di perubahan awal. Jika permasalahan konseli sudah terselesaikan secara lancer dan efektif maka proses konseling dapat diakhiri. Disini konseli didorong agar menjadi konselor untuk dirinya sedniri dengan harapan mampu menerapkan keterampilannya dalam memecahkan masalah yang dihadapi.

Pada penelitian sebelumnya juga membuktikan bahwa mahasiswa yang prokrastinasi mengalami regulasi diri efektif dapat ditingkatkan melalui proses konseling ringkas berfokus solusi (Fernando \& Rahman, 2018). Penelitian tersebut dengan subjek mahasiswa STAIS Majenang menggunakan rancangan penelitian quasi experimental design, berbeda pada penelitian ini menggunakan 4 siswa kelas VIII SMP Muhammadiyah Turi Sleman. Penelitian ini mendapatkan hasil bahwa perbedaan skor regulasi diri terlihat jelas dan signifikan antara perbedaan mahasiswa sebelum dan setelah dilakukan konseling ringkas berfokus solusi. Penelitian tersebut mengambil objek regulasi diri mahasiswa yang mengalami proktrastinasi. Kemudian, Treatment yang digunakan dalam penelitian tersebut menggunakan tahapan teknik berupa exception, solution goals, miracle question, dan scalling. Penelitian tersebut mengambil objek penelitian regulasi diri yang mengalami prokrastinasi sedangkan penelitian ini terfokus pada self-regulated learning.

Penelitian lain juga menyatakan konseling ringkas berfokus solusi efektif digunakan untuk meningkatkan tanggung jawab belajar siswa SMP (Mutakin et al., 2016). Pada penelitian ini menggunakan rancangan A-B-A Penelitian tersebut juga merancangan kuasi eksperimen desain subjek yang digunakan desain tunggal (single subject). berbeda dengan penelitian ini desain ynag digunakan adalah one-group pretest posttest design. Subjek dalam penelitian tersebut menggunakan 6 orang siswa kelas VIII. Penelitian ini menghasilkan bahwa setelah diberikan perlakuan konseling ringkas berfokus solusi menunjukkan bahwa tangung jawab belajar siswa dapat ditingkatkan dan terdapat perbedaan signifkan sehingga menunjukkan peningkatan.

Penelitian lain membuktikan bahwa konseling ringkas berfokus solusi efektif mempunyai pengaruh terhadap self-esteem siswa MTsN (Kaharja \& Latipah, 2017). Penelitian tersebut mengkolaborasikan proses konseling ringkas berfokus solusi berbasis konseling islami. Teknik yang dipakai pada penelitian tersebut menggunakan miracel question, goals setting, exception, dan scales question yang diselipkan makna-makna ajaran islami. Pada penelitian tersebut menggunakan one group pre-test post-tes design dengan subjek penelitian ini berjumlah 4 orang siswa MTsN Bantul Kota. Penelitian ini membuktikan self-esteem siswa dapat ditingkatkan dengan konseling ringkas berfokus 
solusi berbasis islami. Terlihat dari peningkatan nilai skor rata-rata antara pretest dan posttes. Berbeda pada penelitian ini yang hanya fokus pada proses konseling ringkas berfokus solusi tidak di kombinasikan dengan konseling islami dan tahapan teknik yang di gunakan pun berbeda dengan penelitian ini.

Penelitian lain yang dilakukan pada siswa kelas X IPA1 SMA N 1 Mojosari membuktikan bahwa kemampuan komunikasi interpersonal siswa dapat ditingkatkan melalui penerapan konseling ringkas berfokus (Wahyuni, 2015). Penelitian tersebut menggunakan jenis dan desain penelitian pre experimental dengan one group pretest and post test. Instrumen data yang digunakan menggunakan instrumen angket yang di berikan kepada subjek penelitian yang berjumlah 6 siswa, sedangkan penelitian ini instrumen yang digunakan menggunakan skala yang didukung dengan observasi. Terdapat perbedaan skor nilai antara pretest dan posttest, sehingga hasil penelitian tersebut dapat dikatakan efektiv.

Penelitian lain menyebutkan bahwa motivasi berprestasi siswa SMK dapat ditingkatkan melalui proses konseling ringkas berfokus solusi (Wiyono, 2015). Jenis penelitian tersebut menggunakan jenis penelitian eksperimen degan desain pretest posttest control group design, pada penelitian ini menggunakan subjek yang berjumlah 10 siswa kelas $\mathrm{X}$. Konsep pemberian treatment pada penelitian tersebut menggunakan konseling kelompok yang dibagi menjadi dua kelompok dengan peran kelompok yang berbeda diantaranya kelompok eksperimen dan kelompok kontrol. Kelompok eksperimen adalah kelompok pertama dan kelompok kontrol adalah kelompok yang kedua. Hasil penelitian menunjukkan peningkatan motivasi berprestasi lebih tinggi dengan pada kelima konseli yang menjadi kelompok eksperimen dibandingkan dengan kelompok kontrol. Namun berbeda dengan penelitian ini, yang mana treatment dilakukan dengan format konseling individu dan tidak menggunakan kelompok eksperimen maupun kelompok kontrol.

Berdasarkan beberapa pendapat penelitian sebelumnya menyebutkan bahwa penggunaan konseling ringkas berfokus solusi telah berhasil membuktikan keefektivan penggunaan konseling ringkas berfokus solusi dalam mengatasi berbagai permasalahan baik dalam format konseling kelompok maupun konseling individu. Pada penelitian ini peneliti setuju bahwa konseling ringkas berfokus solusi dapat secara efektif digunkan untuk meningkatkan self-regulated learning dengan menggunakan format konseling individual.

Peneliti berusaha dengan maksimal dalam melaksanakan penelitian ini, akan tetapi peneliti menyadari bahwa pada pelaksanaan penelitian ini masih terdapat kekurangan di karenakan keterbatasan dari peneliti. Keterbatasan pertama yang dialami adalah terkait waktu dan tempat. Waktu pelaksanaan pretest dilakukan dengan meminta jam istirahat dan waktu sepulang sekolah karena tidak ada guru BK pada saat penelitian. Selain itu, ketika treatment selama 5 kali pertemuan dan posttest juga memakai waktu sepulang sekolah. Selain itu, keterbatasan lainnya adalah pada penelitian kali ini tidak menggunakan kelompok kontrol melainkan hanya menggunakan satu kelompok eksperimen, seperti jenis kelamin, kebudayaan dan latar belakang siswa. Penelitian konseling ringkas berfokus solusi ini akan lebih optimal apabila menggunakan perbandingan kelompok kontrol.

\section{SIMPULAN}

Berdasarkan hasil penelitian yang telah dilakukan di SMP Muhammadiyah Turi Sleman dapat disimpulkan self-regulated learning pada siswa terbukti meningkat setelah diberikan treatment layanan konseling ringkas berfokus solusi dengan format konseling individual. Sehingga dapat diambil kesimpulan bahwa self-regulated learning secara 
efektif dapat ditingkatkan melalui proses konseling menggunakan teknik konseling ringkas berfokus solusi. Untuk peneliti lainnya disarannkan dapat meneliti permasalahan yang sama, yang terkait dengan self-regulated learning menggunakan pendekatan konseling dengan model konseling lain agar dapat menyempurnakan penelitian yang dilakukan oleh peneliti secara optimal.

\section{UCAPAN TERIMAKASIH}

Ucapan terima kasih disampaikan pada pembimbing pelaksanaan penelitian, sehingga penelitian dapat selesai sampai pada terpublikasinya hasil penelitian. Ucapan terima kasih juga disampaikan pada pimpinan program studi, fakultas, dan universitas di lingkungan Universitas Ahmad Dahlan yang telah memfasilitasi terlaksananya penelitian. Selain itu, ucapan terima kasih juga disampaikan kepada pihak SMP Muhammadiyah Turi Sleman yang telah bersedia menjadi mitra untuk pelaksanaan penelitian.

\section{DAFTAR PUSTAKA}

Alhadi, S., \& Supriyanto, A. (2017). Self-Regulated Learning Concept: Student Learning Progress. Seminar Nasional Bimbingan Konseling Universitas Ahmad Dahlan, 2.

Andrew, S., \& Vialle, W. (1998). Nursing students' self-efficacy, self-regulated learning and academic performance in science. Nursing Times, 76(10), 427-432.

Bembenutty, H. (2007). Self-regulation of learning and academic delay of gratification: Gender and ethnic differences among college students. Journal of Advanced Academics, 18(4), 586-616.

Corey, G. (2015). Theory and practice of counseling and psychotherapy. Nelson Education.

Corey Gerald. (2012). Theory \& Practice of group Counseling (ke 8). Broks / Cole Cengage Learning.

Creswell, J. W. (2009). Research Design California. Sage.

Fernando, F., \& Rahman, I. K. (2018). Efektifitas Solution Focused Brief Therapy (Sfbt) Islami Guna Meningkatkan Regulasi Diri Mahasiswa Yang Mengalami Prokrastinasi. Journal of Innovative Counseling: Theory, Practice, and Research, 2(02), 16-31.

Kaharja, K., \& Latipah, E. (2017). Pengaruh Konseling Islami Solution Focused Brief Therapy Terhadap Self-esteem Siswa Mtsn Bantul Kota Tahun 2015/2016. Jurnal Pendidikan Agama Islam, 13(1), 99-116.

Khafidhoh, I., \& Purwanto, E. (2015). Pengembangan Model Bimbingan Kelompok Dengan Teknik Modeling Untuk Meningkatkan Self-Regulated Learning Pada Siswa Smp N 13 Semarang. Jurnal Bimbingan Konseling, 4(2).

Latipah, E. (2010). Strategi self regulated learning dan prestasi belajar: Kajian meta analisis. Jurnal Psikologi, 37(1), 110-129.

Mukhid, A. (2008). Strategi Self-Regulated Learning (Perspektif Teoritik). TADRIS: Jurnal Pendidikan Islam, 3(2).

Mulyani, D. (2013). Hubungan kesiapan belajar siswa dengan prestasi belajar. Konselor, 2(1).

Mutakin, F., Hidayah, N., \& Ramli, M. (2016). Efektivitas Konseling Ringkas Berfokus Solusi untuk Meningkatkan Tanggung Jawab Belajar Siswa SMP. Jurnal Pendidikan: Teori, Penelitian, Dan Pengembangan, 1(11), 2220-2225.

Nelson, T. S., \& Thomas, F. N. (2012). Miraculous Knowing: Epistemology and Solution-Focused Therapy: Duane R. Bidwell. In Handbook of Solution-Focused Brief Therapy (pp. 89-111). Routledge. 
Panadero, E., Andrade, H., \& Brookhart, S. (2018). Fusing self-regulated learning and formative assessment: A roadmap of where we are, how we got here, and where we are going. The Australian Educational Researcher, 45(1), 13-31.

Pintrich, P. R. (2000). The role of goal orientation in self-regulated learning. In Handbook of self-regulation (pp. 451-502). Elsevier.

Pintrich, P. R., \& De Groot, E. V. (1990). Motivational and self-regulated learning components of classroom academic performance. Journal of Educational Psychology, 82(1), 33.

Rusandi, M. A., \& Rachman, A. (2014). Efektifitas Konseling Singkat Berfokus Solusi (Solution Focused Brief Therapy) Untuk Meningkatkan Self Esteem Mahasiswa Program Studi Bimbingan Konseling Fkip Unlam Banjarmasin. Al'ulum, 62(4).

Saputra, W. N. E., Da Costa, A., \& Alhadi, S. (2018). Creative Solution Focused Counseling Models (CSFCM): Strategi Kreatif untuk Mengembangkan Selfregulated Learning Siswa. Jurnal Kajian Bimbingan Dan Konseling, 3(4), 162170.

Saputra, W. N. E., Wiretna, C. D., Utami, S. R., \& Ramadhani, A. (2018). Drawing Solution: Ekspresi Seni dalam Konseling Ringkas Berfokus Solusi. Jurnal Fokus Konseling, 4(2), 185-191.

Sugiyono, P. D. (2013). Metode Penelitian Manajemen. Bandung: Alfabeta, CV.

Sugiyono, Prof Dr. (2010). Metode penelitian pendidikan. Pendekatan Kuantitatif.

Suharsimi. (2002). Metode Penelitian. Rineka Cipta.

Sumarmo, U. (2004). Kemandirian belajar: Apa, mengapa, dan bagaimana dikembangkan pada peserta didik. Makalah Pada Seminar Tingkat Nasional. FPMIPA UNY Yogyakarta Tanggal, 8.

Sumarwiyah, S., Zamroni, E., \& Hidayati, R. (2015). Solution Focused Brief Counseling (Sfbc): Alternatif Pendekatan Dalam Konseling Keluarga. Jurnal Konseling GUSJIGANG, 1(2).

Wahyuni, I. (2015). Penerapan Solution Focused Brief Therapy (Sfbt) untuk Meningkatkan Kemampuan Komunikasi Interpersonal Siswa Kelas X IPA 1 SMA Negeri 1 Mojosari. Jurnal BK UNESA, 5(2).

Wiyono, B. D. (2015). Keefektifan Solution-Focused Brief Group Counseling untuk Meningkatkan Motivasi Berprestasi Siswa Sekolah Menengah Kejuruan. JKI (Jurnal Konseling Indonesia), 1(1), 29-37.

Woolfolk, A. (2010). Educational psychology: Modular Active Learning Edition. Prentice Hall.

Yulianti, P., Sano, A., \& Ifdil, I. (2016). Self Regulated Learning Siswa Dilihat dari Hasil Belajar. Jurnal EDUCATIO: Jurnal Pendidikan Indonesia, 2(1), 98-102.

Zimmerman, B. J. (1990). Self-regulated learning and academic achievement: An overview. Educational Psychologist, 25(1), 3-17. 